\title{
The Devastation of Soviet Local Studies and Folkloristics
}

\author{
T. G. Ivanova \\ Institute of Russian Literature \\ St. Petersburg, Russia
}

In the 1920s in various cities and even villages of the Soviet Union there existed hundreds of local studies societies which carried out extensive and productive work, investigating local flora and fauna, economics, history, ethnography, and folklore. The system of local studies societies and museums, which encompassed all of Russia, gave the provincial intelligentsia an opportunity for valuable interaction and helped it to realize its knowledge and enthusiasm in matters useful for the country. However, in 1928 and 1929, the solidified Bolshevik regime decided to stifle any independence of public thought in the provinces. According to the formulation of S. O. Shmidt (1989), "what we now call the year 1937 (that is, the worst year of Stalin's purges - trans.) came for local studies in 1929 and 1930" (p. 16).

At the third All-Union Local Studies Conference, which took place in Moscow in December 1927, a change of regime was carried out in the Central Bureau of Local Studies (ТsBК - ЦБК), that is, in the main local studies organ of the Soviet Union. The regular secretary of the Academy of Sciences, the well-known Orientalist S.F. Ol'denburg, conceded his place to the party functionary P.G. Smidovich. Continuing the ideological offensive against local studies, the Bolsheviks strove to oppose the TsBK to its local studies center. In April 1929, a local studies section was organized at the Communist Academy (which, in turn, was created as a counterpart to the "old regime" Academy of Sciences). On October 1, 1930 this section was transformed into the Society of Specialists and Marxists for Local Studies. The journal "Local Studies" (Краеведение), which had been published since 1923, was renamed "Soviet Local Studies" (Советское краеведение). Articles with characteristic titles such as "For Bolshevik vigilance in local studies" turned out to be definitive. At the IV All-Union Local Studies Conference in March 1930, local studies were conclusively subordinated to the Bolshevik regime.

In 1932 one article in "Soviet Local Studies" stated with great satisfaction:

For long years local studies in the USSR were farmed out to the 'old' specialists in local studies. Forced out by history from the course of social and political life, these 'specialists' found a refuge in local studies. Here they 
'sat out their time' until 1929. And after this they carried out their advocacy about the 'political indifference' of science and the distinctive vocation of the specialist in local studies - to strive to learn about one's region in the past and present, and to learn about it 'in general,' that is, outside of class, not only in isolation from the tasks of building socialism and the class struggle of the proletariat, but often also in opposition to these tasks, in the name of 'the sacred past' (святой старины). Hence the prevalence of grave digging in local studies, and the prevalence of populist theories in the history of a region and in its ethnography. From this emerged lairs of sabotage in many local study organizations, lairs which were exposed and revealed (although not unmasked completely) only in the last one-and-a-half to three years (Klabunovskii 1932: 67).

In our opinion, S.O. Shmidt (1997) formulated the reasons for the devastation of Soviet local studies precisely:

The fact of the matter is that local studies societies and in general the work of specialists in local studies were an expression of democratic initiatives which sometimes date back to pre-revolutionary traditions and even to the 'zemstvo' (an elective district council from 1864 to 1917. Trans.). The introduction to the acquisition of knowledge frequently took place by avoiding official channels, and by evading standardized methods and obligatory 'guiding instructions.' This no longer corresponded to the new trends which were generated by circumstances characteristic for the cult of Stalin and the bureaucratization of our public life. Moreover, when they strove to level everything, specialists in local studies considered it their duty to discover originality. By all the experience of their occupation and by the experience of their region's history they cautioned against attempts to unify management methods without taking into account local features, both natural and social, which had been supported by established customs (p. 165).(1)

Arrests and court trials connected with the devastation of local studies took place at the turn of the 1920s and 1930s in various parts of the USSR. Folklorists turned out to be among the specialists in local studies who were arrested and exiled from their native places.

One of those who suffered at that time was the outstanding Russian folklorist Nikolai Evgenevich Onchukov (1872-1942) who discovered the bylina tradition on the Pechora River and compiled a collection of "Northern Tales" (“Северные сказки”) [Onuchkov 1904; Onuchkov 1908]. At the end of the 1920s, Onchukov was living in Leningrad and was working at the Central Bureau of Local Studies. He was arrested on September 1, 1929, and stayed in prison until June 23, 1930, when the verdict of the court exiled him to the city of Nikolsk in the Northern Region (Северный край) which now is called the Vologodskaia oblast'. Onchukov was incriminated for participation in "a counter-revolutionary 
conspiracy in the Bureau of Local Studies." This accusation was specified in the statement of a scholar to the Commission on matters of personal amnesties - P.G. Smidovich. On March 11, 1932, Onchukov wrote to the highest court from Nikolsk:

On September 1, 1930 (an obvious slip of the pen - 1929. T. I.) I was arrested on a charge according to article 58.2, 'membership in a counterrevolutionary organization and an attempt to convert local study organizations into counter-revolutionary organizations.' I not only never belonged to any c(ounter)-r(evolutionary) organization, but I never even dreamed about such an organization. I actually worked in the Central Bureau of Regional Studies, but my work there bore an exclusively scholarly character (according to my specialty I printed two articles and twenty-two reviews in 'Kraevedenie' and in 'Izvestiia TsBK'). I had no connection with any organizational activity and had not attended a single conference for specialists in local studies. I never was an enemy of the Soviet Regime. I always considered that the Soviet Regime was historically inevitable.... (RGB-a).

In the course of the investigation N.E. Onchukov was reminded of his "sins" during the Civil War, that is, his collaboration with the Kolchak regimes in Siberia. This has been established from a note written by Onchukov's wife, Anna Aleksandrovna BulavkinaOnchukova. She most probably prepared the note for V.D. BonchBruevich, an old Bolshevik with a pre-Revolutionary party record. In the post-October period, he worked in the cultural field. In the abovementioned note it is stated,

The essence of the accusation against N. E. in Leningrad boils down to the fact that he wrote against Bolsheviks in newspapers after he happened to be in the occupation of Kolchak ... . Thus the arrest was provoked by the denunciation of a half-insane person who, in his diary enumerated, all local studies specialists who worked in the Leningrad section of the Local Studies Society (in it N. E. served one year as secretary). The whole section was arrested for having planned a conspiracy against the Soviet Regime (RGALIa).

Onchukov's exile, which was provoked by the "case of regional studies," fortunately did not last long. The efforts of the scholar for an early return from exile met with success. By decree of a Special Session at a Commission of the GPU(2) he was permitted to return from administrative exile on May 26, 1932 (RGB-b). On a form issued on June $30^{\text {th }}$ by the local department of the GPU in Nikolsk, the scholar received the standard certification that he was freed from exile and had a 
right to live freely in the USSR (RGALI-b). Onchukov returned to Leningrad. However, on his way to "free residency in the USSR" several obstacles emerged; the authorities refused to give Onchukova, his wife, a permit to live in Leningrad. In the beginning of the 1930s V.D. BonchBruevich tried to improve Onchukov's fate by appealing to S.M. Kirov, the head of the Leningrad party organization (RGALI-c). This stage of Onchukov's purgatory concluded happily; the scholar remained in Leningrad and even received an academic pension.

However, the political atmosphere in the country was growing more ominous. The provocative murder of S.M. Kirov on December 1, 1934 allowed the Stalinist regime to unleash a new campaign of repressions. On April 1, 1935, just like tens of thousands of other representatives of the Russian intelligentsia, Onchukov was expelled from Leningrad. Penza was designated as his place of residency (RGALI-d). Here on October 5, 1939, the aged scholar was arrested again. The trial took place from March 17 to 20,1940. Because he had attended church and in some campaign had condemned the so-called "voluntary" annexation of Western Ukraine and Western Belarus to the USSR, Onchukov was sentenced to ten years deprivation of freedom. The scholar passed away in a prison camp near Penza in March of 1942 (Ivanova 1996(1998): 242-51). Such was the fate of one outstanding collector of Russian folklore. The circumstances of Onchukov's life and death were typical of the Stalinist epoch; once a person had attracted the ominous attention of the punitive organs he, as a rule, became their victim a second and even a third time.

The fate of other Russian folklorists was decided at the turn of the 1920 s to the 1930s in cases against specialists in local studies. The mechanisms for the devastation of local studies "in the provinces" can be examined on the basis of the Voronezh materials (the name then was the Central Black-Earth District - Центрально-Черноземная область). In February 1929, local circles and societies were disbanded and a single organ was created, the District Bureau of Local Studies of the Central Black-Earth District or TsChO (Областное бюро краеведения Центрально-Черноземной области). In the fall of that year, articles were published in the Voronezh press directed against "old-regime" specialists, those working in local studies organizations that had been formed in pre-revolutionary Russia. The labels "pseudo-scholar" and "pseudo-specialist in local studies" were directed, for example, against the learned secretary of the district bureau of local studies, S.N. Vvedenskij. A TsChO conference of specialists in local studies took 
place in January 1930, in Voronezh. At that conference, the Local Society of Regional Studies was renamed and called the Society for the Study of the Local Region the goal of which was to build socialism in the country. At the same time, "deliverance" from the old leadership also took place. The first arrests among specialists in local studies in Voronezh took place over the course of several months, beginning in November 1930. From February to April 1931 arrests were also carried out in Kursk, Tambov, Orel, Staryi Oskol, Lipetsk, Zadonsk, Elets, and Ostrozhosk. As in other such instances, the members of the GPU concocted the mythical Voronezh district counter-revolutionary organization "Specialists in local studies" which supposedly had connections with the mythical "All-National Union of the Struggle for the Liberation of a Free Russia." Repressive authorities claimed that the academician and outstanding historian S.F. Platonov was the head of this organization. Thus the "case" of the specialists in local studies was connected to the "case of the academicians." Authorities arrested a total of ninety-two specialists in local studies in the Central Black-Earth District. The investigation was concluded in May 1931, and on June 5, without holding a trial, a "troika"(3) pronounced the sentences: five people were sentenced to execution; the remainder were sentenced to prison camps and to exile for periods ranging from three to ten years (Akin'shin 1992: 173-78; Akin'shin and Lasunskii 1990: 56-66).

Aleksei Mikhailovich Putintsev (1880-1937), a well known literature scholar and folklorist, was among those arrested in the Voronezh case. A graduate of the History and Philology Faculty in Yurev University (now the city of Tartu in Estonia), he taught in gymnasiums and secondary schools in Tsaritsyn, Samara, Kazan, and Kamyshin from 1906 to 1918. In 1906, Putintsev became a full member of the Voronezh Scholarly Archival Commission, and in 1913, a full member of the Russian Geographic Society. Putintsev's first works, which were connected with Voronezh folklore (materials on the local Trinity ritual, songs, and chastushkas), appeared at the beginning of the twentieth century (Putintsev 1907; 1913a; 1913b). Besides his works on folklore, the scholar also published his early works about the nineteenthcentury Voronezh poets A.V. Kol'tsov and I.S. Nikitin in the "Memorandums of Voronezh Province" (Памятные книжки Воронежской губернии). These works made him one of the founders of joint literary and local studies in Russia (Putintsev 1910; 1913c). From 1920 to 1930 Putintsev was a professor in the Literature and Linguistics Department of the Pedagogical Faculty at Voronezh State University. 
During the devastation of local studies in Voronezh, the scholar was arrested and sentenced to five years in prison camps. His folklore collection of skomoroshinas and chastushkas in Voronezh perished while he was in a camp. The scholar spent part of his sentence on the River Pechora. In 1933, Putintsev was freed and from 1933 to 1935 he worked in Orel in a local pedagogical institute. In 1935 he was a professor for a very short time in the Perm Pedagogical Institute and, from 1936 to 1937, in the Tambov Teacher's Institute. The scholar died from natural causes on May 16, 1937 (Lasunskii 1969; Akin'shin and Lasunskii 1990).

Repressions connected with the devastation of Soviet local studies were directed against another prominent folklorist of the 1920s, Vasilii Ivanovich Smirnov (1882-1941). He was a native of the Pereslavskii District in the Province of Vladimir, a descendant of a family of clergy. He graduated from a Vladimir Religious School (Владимирское духовное училище) and then studied in the History Department of the Moscow Religious Academy (Московская духовная академия). As many representatives of his generation, at a critical moment in his life he changed his religious ideals to socialist ideals. In 1905, in Pereslavl, Smirnov organized a Social-Democratic circle, was arrested, and spent four months in prison. Subsequently he moved to Kostroma where he taught in a local religious seminary and men's gymnasium. With the formation of the Kostroma Scholarly Society for the study of the local region in 1912. Smirnov, who was keenly interested in archeology and ethnography, became its secretary. In 1921 he occupied the post of chairman. Under his direction, the Society became one of the most successful such organizations in the country in the 1920s (Pernet 2001: 15-21).

During the years of its existence from 1912 to 1930, the Kostroma Scholarly Society for the Study of the Local Region published more than sixty works among which were forty-one collections of "Works" (Труды). In the "Second Ethnological Collection" (Второй этнографический сборник), which came out in 1920, Smirnov published an extensive article entitled "Folk Funerals and Lamentations in the Kostroma Region" (Smirnov 1920). Smirnov's article "The Sunken Bells" (потонувшие колокола) which concerns a legend similar to the famous legend about Kitezh, appeared in the "Third Ethnographic Collection" (1923). His article "Folk Divinations of the Kostroma Region" was published in the "Fourth Ethnographic Collection" 
(Smirnov 1927: 17-21). Another work by Smirnov presented rich material on legends about buried treasures (Smirnov 1921).

It should be pointed out that, in the beginning of the $1920 \mathrm{~s}$, Kostroma folklorists had apparently still not fully understood the essence of the new regime and its repressive character. The mechanisms of selfcensorship, by which scholars would be guided in the 1930s, obviously had not yet been elaborated in a scholarly milieu. In his article "The Devil Has Been Born", Smirnov (1923) traced the transformation of old motifs about the birth of the devil under new social and political conditions. The devil, according to numerous variants collected by Smirnov, was born from a peasant woman whose husband, a communist, had committed an outrage against an icon. By the end of the 1920s this kind of publication had become impossible.

When a change in leadership was taking place in the Kostroma Scholarly Society in 1929, V.I. Smirnov, not wishing to see the collapse of what he had created and understanding that events surrounding him could lead to his arrest, moved to Ivanovo. For several years here he worked in the District Museum for Local Studies. In the summer of 1930 he organized archeological excavations near Ivanovo, thereby continuing activities which he had enthusiastically carried on in Kostroma. Smirnov was arrested on November 15, 1930.

The materials of the investigative case against V.I. Smirnov, which were published by L. I. Sizintseva, allow us to understand the accusations of a "professional" nature that were leveled against specialists in local studies in those years. One point in the accusations apparently concerned the fact that local studies, as a particular phenomenon in the cultural life of the country, was in opposition to the centralization of science. For a political regime which strove for absolute control over all spheres of life, local studies, which assumed both initiative and independent action in the provinces, were unacceptable. On October 22, 1930, during his incarceration and while answering a similar accusation, Smirnov explained to the investigators:

My basic idea about the work of local studies was this: a local area needs to be studied no less than the center. This needs to be done in the locality, if possible by local people, after the necessary conditions for this have been created. Knowledge, I judged and continue to think, should not be a property only of central scholars who cannot serve the whole country. Perhaps such an understanding of the questions also can be called the decentralization of knowledge.... It seemed necessary to me to lower the scholarly, or at least the work of collecting material, to the level of the "uezd," then to the "volost'," and finally to the village (selo).... If all this has to be considered anti-Soviet 
decentralization, then this implies no understanding of what local studies are (Sizintseva 1990: 35).

The second point of the accusations advanced against V.I. Smirnov concerned the fact that he, as the head of the Kostroma Scholarly Society, supposedly incorrectly assigned priorities in the activities of the Museum which was part of the Society. From the materials published by L. I. Sizintseva, it follows that one of the members of the Society (in the publication designated as E.A. G-n., higher education, an economist) testified at the inquest that Smirnov "devoted his main attention to questions which were not connected with the national economy, but with descriptions of witches, byliny and $\mathrm{o}<$ ther $>$ pulp having nothing in common with building socialism" (Sizintseva 1990: 34). Another witness (P.V. V-V., a former type-setter, who became a Soviet functionary and who worked in the Kostroma Museum), testified at the inquest:

The ethnological institution which Smirnov managed was such in 1929 that I advocated its liquidation, since it, instead of studying the everyday life of workers, was occupied with the study of superstitions, beliefs, sorcerers, and forms of bread baking. I consider that Smirnov, without a doubt, is a person alien to the existing order; his ideology, without a doubt, is hostile to the policy of the Soviet Regime (Соввласти) and of the party. After the Revolution and while directing the Scholarly Society and Museum, he selected people similar to him in spirit ..., he carried on work which was not directed toward the building of socialism. Both the scholarly society and the Museum were a base for a $<$ nti $>$ Soviet groups with goals of carrying out $\mathrm{a}<$ nti $>$ Soviet and anti-social activities (Sizintseva 1990: 34).

The absurdity of such accusations, which were provoked by the deep ignorance of those who formulated them, does not require any special commentary today.

On January 15, 1931, V.I. Smirnov's sentence was pronounced:

$\mathrm{Ci}<$ tizen $>$ Smirnov was guilty of the following: while being the director of the Kostroma Society of Local Studies and of the Kostroma Museum, he carried out counter-revolutionary directives in the activities of these organizations, received from the Leningrad Bureau of Local Studies, and representing a counter-revolutionary center in local studies (Reshetov 2000: 46).

Accusations of this kind were qualified according to the sadly famous article 58/10 and article 58/11. V. I. Smirnov was sentenced to exile in Archangel. There he succeeded in getting a job in the Northern 
Geolo-Hydro-Geodesic Trust as a specialist on museums. At the Trust the scholar created a geological museum (1932) which exists to the present day. Through a combination of jobs Smirnov, as an archeologist, collaborated with the Archangel District Local Studies Museum (193441), carried out several archeological excavations, and in the years 193436 organized expeditions to the Summer and Winter Shores of the White Sea. He succeeded in publishing the results of this research in the journal "Soviet Ethnography" (Советская этнография). The scholar passed away on October 21, 1941 (see Kuratov 2001; Sizintseva 1992: 263-76; Filimonov 1975; Bochkov 1974).

Together with the accusations formulated by investigators during interrogations, analogous accusations against V. I. Smirnov were reflected in the scholarly literature of the time. Extremely interesting material, characteristic of the period under discussion, appears in the collection of articles entitled "Against Sabotage in Local Studies Literature" (Против вредительства в краеведческой литературе [Ivanovo-Voznesensk], 1931). The collection is based on the papers of the session of the Ivanovo District Society of Historians and Marxists which took place February 17, 1931. While criticizing V. I. Smirnov's brochure "Treasures, Landowners, and Robbers: Ethnographic Essays on the Kostroma Region” (Клады, паны и разбойники: Этнографические очерки Костромского края), G. Ladokha (1931) points out that Smirnov makes no allusion to the "class approach, or to the class analysis of reality" (p. 26). Ladokha even deduced "direct counterrevolutionary attacks" in Smirnov's work. The fault found in one of the scholar's articles relates to stories from the time of the Civil War, especially stories about the leader of the rebellion against the Soviet Regime, Ozerov. In the eyes of Ladokha, the mere mention of Ozerov's name was criminal. "It is difficult to more openly come forward in print against the Soviet Regime" concludes Ladokha. "This article would be a perfect adornment for any white-guard journal" (Ladokha 1931: 28) ("white guard" was a general name for those who fought against the Communist revolution. Trans.).

Another Kostroma folklorist, Mikhail Mikhailovich Zimin, was subjected to attacks in the beginning of the 1930s. We do not know whether Zimin was affected by political repressions or whether he was arrested. The ideological "unmasking" of his articles, like the unmasking of V. I. Smirnov's writings, occurred in the above mentioned collection, “Against Sabotage in Local Studies Literature." Ladokha (1931) pointed out that the publications of Zimin were "ideologically hostile to the 
working class and to the socialist revolution" (p. 27). Citing an extensive passage from one of Zimin's articles, Ladokha (1931) remarks:

In the quoted fragment we find everything one could wish for: a condemnation of the 'huge breakup of the village' and a longing for the vanishing semi-serf everyday life and its 'good old customs' ..., and a deep unconcealed animosity toward the cultural influence of the factory and the city (p. 27).

Ladokha also turned his attention to the publication of recruit laments which Zimin recorded in 1919.

The essence of Zimin's publication is as follows. In his introductory remarks reflecting objective reality, the folklorist indiscreetly contrasted the pre-Revolutionary recruit ritual with mobilizations for the Red Army during the Civil War. The collector wrote:

The people's grief became especially deep, during present day mobilizations. In August 1919 during a trip to the Kovernin and Makar'ev districts I happened to see farewells with 'deserters.' They gathered in large parties and walked on foot. They were mourned over as dead men or as people who had alreday been sentenced to death. They were seen off as though to 'certain' death which they would meet either at war or in Kostroma (Zimin 1920: 2).

In the material recorded by Zimin in 1919 we can read the following in a mother's lament over her son while he was being taken into the Red Army and:

Из-за ково ты воевать пошел, ладо милое?

Уж власти все безбожные,

Уж постам-то они не постилися,

Уж не почитали ни среды, ни пятницы

Уж взяла бы я в праву рученьку саблю вострую,

И срубила бы я буйну голову начальникам (Zimin 1920: 8-9).

[Because of whom have you gone to fight, my dear beloved?

All the authorities are unbelievers,

They haven't observed fasting,

They have observed neither Wednesday nor Friday

I would have taken a sharp saber in my right hand,

And I would have cut off the heads of the commanders.]

Ladokha commented on Zimin's article in the following way: 
"Here we see before us specific counter-revolutionary and anti-Soviet writings, written absolutely openly, and again one has to be amazed that all this could have come to pass in our Soviet publications and rather than in foreign literature" (p. 28).

Ladokha's article and those similar to it became for many years a model for the Soviet study of folklore.

By 1931, the field of Soviet local studies, which had been one of the most important elements in the development of the study of folklore in the 1920s, was totally decimated. Societies for local studies continued to exist formally, but the atmosphere of freedom, which had permitted realization of the creative efforts by tens of thousands of people in all parts of the country, was destroyed. Local studies societies were officially closed in 1937.

\section{NOTES}

1 See also about the local studies in 1917-1930: Fleiman, E. A. 2001. Флейман Е.А. Краеведческое движение в Поволжье в 19171930 г.: идеи, события, люди [The Local Studies Movement in Povolzh'e 1917-1930: Ideas, Events, People]. Кострома.

2 GPU (Главное политическое управление) was the main punitive organ - a predecessor of the KGB (Комитета государственной безопасности).

3 "Troika" - an extra-judicial organ of Stalin's time consisting of three people and issuing exclusively guilty verdicts.

\section{BIBLIOGRAPHY:}

Akin'shin, А. N. 1992. Акиньшин А.Н. “Судьба краеведов (конец 20x - начало 30-х годов)" [The Fate of the Local Studies Specialists (end of the 1920s - beginning of the 1930s], Вопросы истории 6/7: 173-178.

Akin'shin, A. N., Lasunskii, O. 1990. Акиньшин А., Ласунский О. ““"Дело краеведов” Центрального Черноземья” [“Court Case of the Local Studies Specialists" Central Black-Earth District], Отечество: Краеведческий альманах 1: 56-66.

Bochkov, V. 1974. Бочков В. "Подвижники костромского краеведения: В.Смирнов [Activists in Kostroma Region Local Studies]" in Bторое дыхание: Глазами краеведов [The Second 
Breath: Through the Eyes of the Local Studies Specialists]. Ярославль, 42-61.

Filimonov, S. В. 1975. Филимонов С.Б. “Эпистолярный архив В.И.Смирнова" [Epistolary Archive of V. I. Smirnov], Археологический ежегодник за 1974 год: 315-323.

Ivanova, Т. G. 1996(1998). Иванова Т.Г. "Новые материалы к биографии Н.Е.Ончукова" [New Biographical Materials of N. E. Onchukov], Russian Studies: Ежеквартальник русской филологии и культуры 2(4): 242-251.

Klabunovskii, I. G. 1932. Клабуновский И.Г. "Через советское краеведение - к освоению естественных богатств страны” [From Soviet Local Studies to Development of the Country's Natural Resources], Советское краеведение 5: 67.

Kuratov, А. А. 2001. Куратов А.А. "Смирнов Василий Иванович” in Поморская энииклопедия [Encyclopedia of the Pomor Land], Ed. В.Н.Булатов. Архангельск. 1: 373-374.

Ladokha, G. 1931. Ладоха Г. "Историческая и этнографическая "наука" в издании костромских краеведов" [Historic and Ethnographic "Scholarship" in Publications of Kostroma Ethnographers] in Против вредительства в краеведческой литературе [Against Sabotage in Local Studies Literature]. Иваново-Вознесенск.

Lasunskii, O. G. 1969. Ласунский О.Г. А.М. Путинцев - историк литературы, фольклорист и этнограф. Краткий очерк деятельности и библиография трудов [A. M. Putintsev - a Historian of Literature; a Folklorist and an Ethnographer. A Short Essay on His Work and a Bibliography]. Воронеж.

Onuchkov, N. Е. 1904. Ончуков Н.Е. "Печорские былины” [Legends of the Pechora Region], Записки императорского Русского географического общества по отделению этнографии. СанктПетербург, vol. 30.

Onuchkov, N. E. 1908. Ончуков Н.Е. "Северные сказки” [Northern Folk Tales], Записки императорского Русского географического общества по отделению этнографии. Санкт-Петербург, vol. 33. Pernet, S. 2001. Пернет C. "Василий Иванович Смирнов как ученый и личность" [Vasilii Ivanovich Smirnov as a Scholar and an Individual], Вестник Костромской археологической экспедиции 1: $15-21$. 
Putintsev, A. М. 1907. Путинцев А.М. “Вымерший народный обычай" [A Folk Custom which has Disappeared], Памятная книжка Воронежской губернии на 1907 год, Отд. 3: 32-33.

Putintsev, A. М. 1910. Путинцев А.М. "Песни Кольцова и народные в отношении приемов поэтического творчества" [Kol'tsov's Songs and Folk Songs as a Means of Poetic Creativity], Памятная книжка Воронежской губернии на 1910 год, Отд. 3: 47-55.

Putintsev, A. М. 1913a. Путинцев А.М. "Талагайская свадьба" [Talagai Wedding], Памятная книжка Воронежской губернии на 1913 год, Отд. 3: 94-119.

Putintsev, A. М. 1913b. Путинцев А.М. “Собрание народных песен из сел: Старой Хворостани, Машкина, Аношкина и Бодеевки Короткоякского уезда Воронежской губернии" [A Collection of Folk Songs from the Villages of Staraia Khvorostan', Mashkino, Anoshkino and Bodeevka from the Korotianskii region, Voronezh District], Памятная книжка Воронежской губернии на 1913 год, Отд. 3: 119-134.

Putintsev, A. М. 1913c. Путинцев А.М. “Детство и юность И.С.Никитина" [Childhood and Youth of I. S. Nikitin], Памятная книжка Воронежской губернии на 1912 год, Отд. 3: 1-158.

Reshetov, A. М. 2000. Решетов А.М. "Смирнов В.И. Архангельские туеса" [Smirnov V. I. Birch-Bark Vessels of the Arkhangel'sk Region], Живая старина 3: 46.

RGALI-a. Российский государственный архив литературы и искусства [Russian State Archive of Literature and the Arts], фонд 1366, опись 2, N 11, л.11.

RGALI-b. Российский государственный архив литературы и искусства, фонд 1366, оп.1, N 115.

RGALI-c. Российский государственный архив литературы и искусства, фонд 1366, оп.1, N 118.

RGALI-d. Российский государственный архив литературы и искусства, фонд 1366, оп.2, N 11, л.2.

RGB-a. Российская государственная библиотека [Russian State Library], Отдел рукописей, фонд 369, коробка 312, N 20, л.1.

RGB-b. Российская государственная библиотека, Отдел рукописей, фонд 369, к.312, N 16, л.1.

Shmidt, S. О. 1989. Шмидт С.О. "Краеведение - дело, значение которого не может быть преувеличено" [Local Studies: An Event the Importance of which cannot be Exaggerated], Памятники Отечества 1 (19): 16. 
Shmidt, S. О. 1997. Шмидт С.О. “Краеведение в научной и общественной жизни России 1920-х годов" [Local Studies in Russia's Scientific and Public Life in the 1920s], in Шмидт C.O. Путь историка: Избранные труды по источниковедению и историографии [A Historian's Path: Selected Works on Primary Source Study and Historiography]. M. 165.

Sizintseva, L. 1990. Сизинцева Л. “Антисоветский” музей: краеведение глазами ГПУ” [An “Anti-Soviet" Museum: Local Studies through the Eyes of the GPU], Родина 11.

Sizintseva, L. V. 1992. Сизинцева Л. В. "И.Смирнов (1882-1941)" [I. Smirnov (1882-1941)], Отечество: Краеведческий альманах 5: 263-276.

Smirnov, V. I. 1920. Смирнов В.И. "Народные похороны и причитания в Костромском крае" [Folk Funerals and Laments in the Kostroma Region], Труды Костром. науч. о-ва по изучению местного края 15: 21-126.

Smirnov, V. I. 1921. Смирнов В.И. “Клады, паны и разбойники: Этногр. очерки Костромского края" [Treasures, Landowners, and Robbers: Ethnographic Essays on the Kostroma Region], Tpydbl Костром. науч. о-ва по изучению местно края 26.

Smirnov, V. I. 1923. Смирнов В.И. "Черт родился (творимая легенда)" [The Devil Has Been Born (A Legend in Creation)], Труды Костром. науч. о-ва по изучению местного края 29: 1720.

Smirnov, V. I. 1927. Смирнов В.И. "Народные гаданья Костромского края" [Folk Divinations of the Kostroma Region], Tруды Костром. науч. о-ва по изучению местного края 41: 17-21.

Zimin, M. 1920. Зимин М. "Плачи по призванным на военную службу (Из записей в Ковернинском крае Костромской губ., в 1916 и 1919 годах)" [Laments for Military Recruits], Труды Костром. науч. о-ва по изучению местного края 15: 2.

Translated by James Bailey 